Ilmu Pertanian (Agricultural Science)

Vol. 2 No. 2 August, 2017 : 093-099

Available online at http://journal.ugm.ac.id/jip

DOI: doi.org/10.22146/ipas.25805

ILMU PERTANIAN
(AGRICULTURAL SCIENCE)

\title{
Application of Lime and Gypsum and Their Effect on Micronutrients (Fe, Zn, Mn, and Cu) Uptake of Sugarcane Planted in Central Lampung Ultisols
}

\author{
C. Sudrajat Widiarso*, Benito Heru Purwanto, Eko Hanudin, Azwar Ma'as \\ Department of Soil Science, Faculty of Agriculture, Universitas Gadjah Mada \\ Jln. Flora no. 1, Bulaksumur, Sleman, Yogyakarta 5528, Indonesia \\ *Corresponding email: arisudradjat61@gmail.com
}

Received: 9 $9^{\text {th }}$ June 2017 ; Revised: $21^{\text {st }}$ July 2017 ; Accepted: $28^{\text {th }}$ August 2017

\begin{abstract}
Most of sugarcane are cultivated on Ultisols with low inherent soil fertility in Central Lampung. This experiment aimed to observe the effect of lime $\left(\mathrm{CaCO}_{3}\right)$ and gypsum $\left(\mathrm{Ca}_{2} \mathrm{SO}_{4}\right)$ on $\mathrm{Fe}, \mathrm{Zn}, \mathrm{Mn}$, and $\mathrm{Cu}$ uptake of sugarcane. The experiment was conducted in Experimental Research Field of Gula Putih Mataram Enterprise, Central Lampung District. The experiment was designed using a split-plot, which consisted of lime application as the main plot and gypsum application as the sub plot with three replications. The results showed that there were no significant influence of lime and gypsum application on micronutrient content of the soil. However, application of 2 and 3 tons of lime/ha could reduce soil Fe content about 349.86 and $328.07 \mathrm{ppm}$ respectively within 0-20 cm soil in depth and it was significantly lower than comparing to Fe content (around $457.68 \mathrm{ppm}$ ) in control. Similarly, the effect of gypsum application at 0.25 ton.ha ${ }^{-1}$ decreased Fe content (355.42 ppm), while Fe content of non-gypsum application soil showed around $410.34 \mathrm{ppm}$. The analysis of other micronutrients did not indicate asignificant effect of lime or gypsum application.
\end{abstract}

Keywords: Gypsum, Lime, Micro Nutrient, Sugarcane

\section{INTRODUCTION}

Sugarcane (Saccharum officinarum L.) is a perennial true grasses grown as asugar-producing plant (Loganadhan et al., 2012; Wijayanti, 2008). Suitable soil structure for sugarcane is loose soil which helps soil aeration and root development. Sugarcane grows well insoil which has $\mathrm{pH}$ of 6-7.5, although it is capable of growing under soil $\mathrm{pH}$ not higher than 8.5 or not lower than 4.5. At high $\mathrm{pH}$, the availability of nutrients becomes limited. On the other hand, plants will exhibit $\mathrm{Fe}$ and $\mathrm{Al}$ toxicity at soil pH less than 5 (Indrawanto et al., 2010; Augstburger et al., 2002). Maintaining soil organic matter content is an important key to sustainable agriculture (Swift dan Woomer, 1993; Basanta et al., 2003). The availability of $\mathrm{K}$ in soils is generally low due to high absorption of $\mathrm{K}$ in sugarcane (Chorom et al., 2009). The absorption of potassium recorded at about 0.71 $\mathrm{kg}$ ha- 1 for sugarcane and $0.95 \mathrm{~kg}$ ha- 1 for ratoon (Malavolta, 1994)

Ultisolsis widely spread in Indonesia, which covers almost $25 \%$ of total area of the country. This type of soil has animportant role in the development of dryland agriculture in Indonesia (Hardjowigeno, 1987). Macro nutrients such as phosphorus and potassium are often deficient in these soils. Soil reaction varies from acidic to very acidic and high saturation of aluminum are the properties of ultisols which often inhibits plant growth. In addition, the existence of argillic horizon affects soil properties such as reductionmicro and macro pores and increase of surface flow, which in turn lead to soil erosion (Prasetyo dan Suriadikarta, 2006; Hardjowigeno, 1987; Alloway, 1997).

In acidic mineral soil, the main soil acidity is $\mathrm{Al}_{3}{ }^{+}$ which contributes $\mathrm{H}^{+}$to soil solution through a hydrolysis process (Dariah et al., 2015). Calcification is an effort to increase soil $\mathrm{pH}$ by addition of lime to soil. The main purpose of calcification is to increase soil $\mathrm{pH}$ from acid-to-neutral, thus decreasing the solubility of $\mathrm{Al}_{3}{ }^{+}$in soil. In acidic soil, macro nutrients $(\mathrm{N}, \mathrm{P}$, $\mathrm{K}, \mathrm{Ca}, \mathrm{Mg}$, and $\mathrm{S}$ ) are less available for the plant due to thetheir low solubility. On the contrary, toxic elements such as $\mathrm{Al}$ and $\mathrm{Fe}$ are available in high concentration. Therefore,calcification is expected to neutralize the soil $\mathrm{pH}$ which increase the availability of macro nutrients to the plants (Alloway, 1997; Hardjoloekito, 2009). 
Two types of lime commonly used in agriculture are calcite and gypsum. Calcite $\left(\mathrm{CaCO}_{3}\right)$ contains $\mathrm{Ca}$ by $40 \%$ while gypsum $\left(\mathrm{CaSO}_{4} .2 \mathrm{H}_{2} \mathrm{O}\right)$ contains 18 $22 \% \mathrm{Ca}$ and $12-18 \% \mathrm{~S}$. Gypsum as one of the more easily soluble $\mathrm{Ca}$ of calcite, making it easier to leach. Lime will affect soil $\mathrm{pH}$ at certain dosages while gypsum supplies $\mathrm{Ca}$ and $\mathrm{S}$, but it does not affect soil $\mathrm{pH}$. However, with its solubility, gypsum can overcome the deficiency of $\mathrm{Ca}$ in subsoil layer. Applying calcite in certain dosages may result in an increase of soil $\mathrm{pH}$ but may also cause excessive calcification (overliming), so that the availability of $\mathrm{Fe}, \mathrm{Mn}, \mathrm{Zn}$, and $\mathrm{Cu}$ elements decreases. The application of gypsum tosoil is known to supply $\mathrm{Ca}$ but it is not affect the soil $\mathrm{pH}$ so that it is necessary to compare the effect of gypsum application on the availability of macro nutrients. The objectives of the research were to investigate the effect of lime $\left(\mathrm{CaCO}_{3}\right)$ and gypsum $\left(\mathrm{Ca}_{2} \mathrm{SO}_{4}\right)$ application as well as its interaction on uptake ofFe, $\mathrm{Zn}, \mathrm{Mn}$, and $\mathrm{Cu}$ of sugarcane on Ultisols.

\section{MATERIALS AND METHODS}

The research was conducted in Experimental Research Field of Gula Putih Mataram Enterprise, Central Lampung District in November 2013 until May 2014. The materials used are ultisols, sugarcane seedlings of TC-09, lime $\left(\mathrm{CaCO}_{3}\right)$ with $92.5 \%$ purity, gypsum $(\mathrm{CaO}$ content by $30.29 \%$ and $\mathrm{S}$ content by $22.01 \%$ ), fertilizers such as ZA, urea, TSP, and $\mathrm{KCl}$. Tools used are plastic drums for sugarcane planting, oven, $\mathrm{pH}$ meter, EC meter, spectrophotometer, and AAS.

The soils were sampled from Experimental Research Field of Gula Putih Mataram Enterprise which previously had been brushing by harrows to cut and chop the stumps. The soil was rejuvenated and re-harrowed twice. Drums with $56 \mathrm{~cm}$ and $60 \mathrm{~cm}$ height were afield with soil with $40 \mathrm{~cm}$ height. Then the soil was compressed with a pressure of $400 \mathrm{~N}$. Mixture of soil-gypsum-lime was added until it reached 20 $\mathrm{cm}$ height. Therefore, there was $120 \mathrm{~kg}$ of soil in a drum. All treatments received the same type of fertilizers which were ZA, urea, TSP, and $\mathrm{KCl}$ at about 5, $14.2,5$ and 12 gram per drum.

The same soils were used for materials of research done by Rusyanto et al (2017). Split-plot experimental design with 3 replications was used for data processing.The lime application $\left(\mathrm{L}=\mathrm{CaCO}_{3}\right)$ as the main plot with 4 levels, which are the dosage of lime starting from $0,1,2$, and 3 tons ha $^{-1}$. While the application of gypsum $\left(\mathrm{G}=\mathrm{CaSO}_{4} \cdot 2 \mathrm{H}_{2} \mathrm{O}\right)$ as the sub plot with 4 levels, which are the dosage of gypsum starting from $0,0.25,0.5$ and 1 ton $\mathrm{ha}^{-1}$. The parameters observed were micronutrient content $(\mathrm{Fe}, \mathrm{Mn}, \mathrm{Cu}$, and $\mathrm{Zn}$ ) of soil divided by two type of depth: 0-20 $\mathrm{cm}$ depth and 20-40 cm depth. Brix value of cane juice was also tested.In order to determine the effect of lime and gypsum on various observed parameters, the results were analyzed using Analysis of Variance. If there was anysignificant difference in the treatments, it was tested further using Duncan's Multiple Range Test at 5\%.

\section{RESULT AND DISCUSSION}

One of the factors that influence the plant growth and optimum production of theplant is soil $\mathrm{pH}$. Soil reactions categorized resistant to $\mathrm{pH}$ indicate the acidity or concentration of $\mathrm{H}^{+}$and $\mathrm{OH}-$ ions exist in thesoil. Table 1 and 2 displays there are no significant interaction between lime and gypsum dosage to soil acidity in both soil depth $(0-20 \mathrm{~cm}$ depth and 20-40 $\mathrm{cm}$ depth). Each factor either lime or gypsum also did not show any significant differences. It can be concluded that the application of lime and gypsum have not been able to increase soil $\mathrm{pH}$ in sugarcane crops.

The analysis of variance show there were no significant interactions between calcite and gypsum application to Fe content in soil within $0-20 \mathrm{~cm}$ and $20-40 \mathrm{~cm}$ depth (Table 3 and 4). Within 20-40 $\mathrm{cm}$ depth, the effect of lime or gypsum also did not show significant influence on Fe content in thesoil. Moreover, it was shown that within $0-20 \mathrm{~cm}$ depth, applying lime could reduce Fe content in the application of 2 and 3 ton $\mathrm{ha}^{-1}$ at about 349.86 and $328.07 \mathrm{ppm}$. These two applications show significant differences compare to the application of 0 ton ha ${ }^{-1}$ which gives higher $\mathrm{Fe}$ content at about $457.68 \mathrm{ppm}$. This indicates that by giving lime as much as 2 ton ha ${ }^{-1}$ could decrease $\mathrm{Fe}$ content in thesoil. Similarly, gypsum application shows adecrease in $\mathrm{Fe}$ content for the application of 0.25 tons ha $^{-1}$ at $355.42 \mathrm{ppm}$, compared to no gypsum which shows Fe content at about 410.34 ppm.

Manganese is absorbed by plant in the form of $\mathrm{Mn}_{2}{ }^{+}$ion. The presence of plant toxicity by manganese in sugarcane is often characterized by the emergence of black spots. The application of lime and gypsum showed no significant influence on soil Mn content of 0-20 $\mathrm{cm}$ and 20-40 $\mathrm{cm}$ depth (Table 5 and 6), except for application of lime with 3 ton ha ${ }^{-1}$ which decreased soil Mn content of 20-40 cm depth. This indicated that the application of lime and gypsum have not been able to reduce Mn content.

The sources of $\mathrm{Cu}$ in thesoil are mainly secondary 
Table 1. The effect of lime and gypsum application to soil $\mathrm{H}_{2} \mathrm{O}$ pH within $0-20 \mathrm{~cm}$ depth

\begin{tabular}{|c|c|c|c|c|c|}
\hline \multirow{2}{*}{$\begin{array}{c}\text { Lime } \\
\left(\text { ton } \mathrm{ha}^{-1}\right)\end{array}$} & \multicolumn{4}{|c|}{ Gypsum (ton ha' ${ }^{-1}$ ) } & \multirow{2}{*}{ Rerata } \\
\hline & 0 & 0.25 & 0.5 & 1 & \\
\hline 0 & 5.72 & 5.77 & 5.82 & 5.69 & $5.75 \mathrm{a}$ \\
\hline 1 & 5.94 & 5.77 & 5.90 & 5.90 & $5.88 \mathrm{a}$ \\
\hline 2 & 6.05 & 6.06 & 6.11 & 6.17 & $6.10 \mathrm{a}$ \\
\hline 3 & 5.98 & 5.82 & 5.90 & 5.98 & $5.92 \mathrm{a}$ \\
\hline er & $92 \mathrm{p}$ & $5.85 \mathrm{p}$ & $5.93 \mathrm{p}$ & $5.93 \mathrm{p}$ & - \\
\hline
\end{tabular}

Remark : The average number followed by the same letter in row or column shows no significant difference based on DMRT at 5\%; (-) : no significant interaction

Table 2. The effect of lime and gypsum application to soil $\mathrm{H}_{2} \mathrm{O}$ pH within $20-40 \mathrm{~cm}$ depth

\begin{tabular}{|c|c|c|c|c|c|}
\hline \multirow{2}{*}{$\begin{array}{c}\text { Lime } \\
\text { (ton ha-1) }\end{array}$} & \multicolumn{4}{|c|}{ Gypsum (ton ha ${ }^{-1}$ ) } & \multirow{2}{*}{ Rerata } \\
\hline & 0 & 0.25 & 0.5 & 1 & \\
\hline 0 & 5.38 & 5.24 & 5.11 & 5.27 & $5.25 \mathrm{a}$ \\
\hline 1 & 5.44 & 5.64 & 5.40 & 5.29 & $5.44 \mathrm{a}$ \\
\hline 2 & 5.75 & 5.50 & 5.51 & 5.85 & $5.65 \mathrm{a}$ \\
\hline 3 & 5.42 & 5.41 & 5.94 & 5.52 & $5.57 \mathrm{a}$ \\
\hline 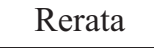 & $50 \mathrm{p}$ & $5.45 \mathrm{p}$ & $5.49 \mathrm{p}$ & $5.48 \mathrm{p}$ & 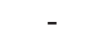 \\
\hline
\end{tabular}

Remark : The average number followed by the same letter in row or column shows no significant difference based on DMRT at 5\%; (-) : no significant interaction

Table 3. The effect of lime and gypsum application to available Fe content in soil (ppm) within 0-20 cm depth

\begin{tabular}{|c|c|c|c|c|c|}
\hline \multirow{2}{*}{$\begin{array}{c}\text { Lime } \\
\left(\text { ton } \mathrm{ha}^{-1}\right)\end{array}$} & \multicolumn{4}{|c|}{ Gypsum (ton ha-1) } & \multirow{2}{*}{ Rerata } \\
\hline & 0 & 0.25 & 0.5 & 1 & \\
\hline 0 & 463.34 & 425.22 & 451.05 & 491.09 & 457.68 \\
\hline 1 & 392.11 & 363.54 & 418.39 & 405.80 & 39 \\
\hline 2 & 368.50 & 343.14 & 359.89 & 327.92 & 349.00 \\
\hline 3 & 417.42 & 289.76 & 292.09 & 313.00 & 328.07 \\
\hline & 10.9 & $50.72 \mathrm{P}$ & Py & 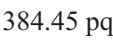 & \\
\hline
\end{tabular}

Remark : The average number followed by the same letter in row or column shows no significant difference based on DMRT at 5\%; (-) : no significant interaction

Table 4. The effect of lime and gypsum application to available Fe content in soil (ppm) within 20-40 cm depth

\begin{tabular}{cccccc}
\hline \multirow{2}{*}{$\left.\begin{array}{c}\text { Lime } \\
(\text { ton ha }\end{array}{ }^{-1}\right)$} & \multicolumn{5}{c}{ Gypsum $\left(\right.$ ton ha $\left.{ }^{-1}\right)$} \\
\hline 0 & 352.30 & 362.31 & 305.12 & 369.67 & $347.35 \mathrm{a}$ \\
1 & 364.45 & 323.40 & 355.50 & 326.52 & $342.47 \mathrm{a}$ \\
2 & 414.07 & 291.55 & 308.27 & 317.24 & $332.78 \mathrm{a}$ \\
3 & 307.24 & 290.01 & 242.86 & 237.02 & $269.28 \mathrm{a}$ \\
\hline Rerata & $359.51 \mathrm{p} 316.82 \mathrm{p} 302.94 \mathrm{p} 312.61 \mathrm{p}$ & - \\
\hline Remark : The average number followed by the same letter in row \\
or column shows no significant difference based on \\
\multicolumn{5}{c}{ DMRT at 5\%; (-) : no significant interaction }
\end{tabular}

Table 5. The effect of lime and gypsum application to available Mn content within 0-20 cm depth

\begin{tabular}{cccccc}
\hline \multirow{2}{*}{$\begin{array}{c}\text { Lime }(\text { ton } \\
\left.\text { ha }^{-1}\right)\end{array}$} & \multicolumn{5}{c}{ Gypsum $($ ton ha } \\
\cline { 2 - 5 } & 0 & 0.25 & 0.5 & 1 & Rerata \\
\hline 0 & 11.19 & 7.25 & 6.97 & 10.09 & $8.87 \mathrm{a}$ \\
1 & 8.74 & 6.30 & 7.07 & 8.13 & $7.56 \mathrm{a}$ \\
2 & 7.69 & 7.33 & 4.42 & 7.07 & $6.63 \mathrm{a}$ \\
3 & 6.76 & 5.33 & 4.64 & 3.84 & $5.14 \mathrm{a}$ \\
\hline Rerata & $8.60 \mathrm{p}$ & $6.56 \mathrm{p}$ & $5.78 \mathrm{p}$ & $7.28 \mathrm{p}$ & - \\
\hline
\end{tabular}

Remark : The average number followed by the same letter in row or column shows no significant difference based on DMRT at 5\%; (-) : no significant interaction

Table 6. The effect of lime and gypsum application to available Mn content within 20-40 cm depth

\begin{tabular}{cccccc}
\hline \multirow{2}{*}{$\begin{array}{c}\text { Lime (ton } \\
\left.\text { ha }^{-1}\right)\end{array}$} & \multicolumn{5}{c}{ Gypsum $($ ton ha } \\
\cline { 2 - 5 } ) & 0 & 0.25 & 0.5 & 1 & \\
\hline 0 & 9.21 & 5.82 & 5.93 & 5.84 & $6.70 \mathrm{~b}$ \\
1 & 6.11 & 7.00 & 6.78 & 5.27 & $6.29 \mathrm{~b}$ \\
2 & 7.17 & 6.00 & 4.54 & 6.01 & $5.93 \mathrm{~b}$ \\
3 & 3.77 & 4.04 & 4.37 & 3.23 & $3.85 \mathrm{a}$ \\
\hline Rerata & $6.56 \mathrm{p}$ & $5.71 \mathrm{p}$ & $5.40 \mathrm{p}$ & $5.09 \mathrm{p}$ & - \\
\hline
\end{tabular}

Remark : The average number followed by the same letter in row or column shows no significant difference based on DMRT at 5\%; (-) : no significant interaction

Table 7. The effect of lime and gypsum application to available $\mathrm{Cu}$ content in soil (ppm) within 0-20 cm depth

\begin{tabular}{cccccc}
\hline \multirow{2}{*}{$\begin{array}{c}\text { Lime (ton } \\
\left.\text { ha }^{-1}\right)\end{array}$} & \multicolumn{5}{c}{ Gypsum $($ ton ha } \\
\cline { 2 - 5 } & 0 & 0.25 & 0.5 & 1 & \\
\hline 0 & 0.32 & 0.32 & 0.33 & 0.33 & $0.33 \mathrm{a}$ \\
1 & 0.35 & 0.36 & 0.37 & 0.29 & $0.34 \mathrm{a}$ \\
2 & 0.28 & 0.31 & 0.31 & 0.31 & $0.30 \mathrm{a}$ \\
3 & 0.30 & 0.30 & 0.29 & 0.34 & $0.31 \mathrm{a}$ \\
\hline Rerata & $0.32 \mathrm{p}$ & $0.32 \mathrm{p}$ & $0.33 \mathrm{p}$ & $0.32 \mathrm{p}$ & - \\
\hline
\end{tabular}

Remark : The average number followed by the same letter in row or column shows no significant difference based on DMRT at 5\%; (-) : no significant interaction

Table 8. The effect of lime and gypsum application to available $\mathrm{Cu}$ content in soil (ppm) within 20-40 cm depth

\begin{tabular}{cccccc}
\hline \multirow{2}{*}{$\begin{array}{c}\text { Lime (ton } \\
\left.\text { ha }^{-1}\right)\end{array}$} & \multicolumn{5}{c}{ Gypsum $($ ton ha } \\
\cline { 2 - 5 } & 0 & 0.25 & 0.5 & 1 & \\
\hline 0 & 0.31 & 0.32 & 0.33 & 0.32 & $0.32 \mathrm{a}$ \\
1 & 0.35 & 0.35 & 0.31 & 0.30 & $0.33 \mathrm{a}$ \\
2 & 0.30 & 0.30 & 0.30 & 0.32 & $0.31 \mathrm{a}$ \\
3 & 0.30 & 0.30 & 0.29 & 0.35 & $0.31 \mathrm{a}$ \\
\hline Rerata & $0.31 \mathrm{p}$ & $0.32 \mathrm{p}$ & $0.31 \mathrm{p}$ & $0.32 \mathrm{p}$ & - \\
\hline
\end{tabular}

Remark : The average number followed by the same letter in row or column shows no significant difference based on DMRT at 5\%; (-) : no significant interaction 
Table 9. The effect of lime and gypsum application to available $\mathrm{Zn}$ content in soil (ppm) within 0-20 cm depth

\begin{tabular}{|c|c|c|c|c|c|}
\hline \multirow{2}{*}{$\begin{array}{c}\text { Lime } \\
\left(\text { ton } \mathrm{ha}^{-1}\right)\end{array}$} & \multicolumn{4}{|c|}{ Gypsum (ton ha-1) } & \multirow{2}{*}{ Rerata } \\
\hline & 0 & 0.25 & 0.5 & 1 & \\
\hline 0 & 0.38 & 0.46 & 0.33 & 0.48 & $0.41 \mathrm{a}$ \\
\hline 1 & 0.44 & 0.36 & 0.51 & 0.37 & $0.42 \mathrm{a}$ \\
\hline 2 & 0.19 & 0.36 & 0.27 & 0.32 & $0.29 \mathrm{a}$ \\
\hline 3 & 0.28 & 0.25 & 0.28 & 0.29 & $0.27 \mathrm{a}$ \\
\hline Rerata & $0.32 \mathrm{p}$ & $0.36 \mathrm{p}$ & $0.35 \mathrm{p}$ & $0.37 \mathrm{p}$ & - \\
\hline
\end{tabular}

Table 10. The effect of lime and gypsum application to available $\mathrm{Zn}$ content in soil (ppm) within 20-40 cm depth

\begin{tabular}{cccccc}
\hline \multirow{2}{*}{$\left.\begin{array}{c}\text { Lime } \\
\text { (ton ha }\end{array}{ }^{-1}\right)$} & \multicolumn{5}{c}{ Gypsum $\left(\right.$ ton ha $\left.{ }^{-1}\right)$} \\
\cline { 2 - 5 } & 0 & 0.25 & 0.5 & 1 & \\
\hline 0 & 0.27 & 0.36 & 0.28 & 0.27 & $0.30 \mathrm{a}$ \\
1 & 0.24 & 0.18 & 0.18 & 0.27 & $0.22 \mathrm{a}$ \\
2 & 0.19 & 0.23 & 0.33 & 0.28 & $0.26 \mathrm{a}$ \\
3 & 0.14 & 0.24 & 0.15 & 0.35 & $0.22 \mathrm{a}$ \\
\hline Rerata & $0.21 \mathrm{p}$ & $0.25 \mathrm{p}$ & $0.24 \mathrm{p}$ & $0.29 \mathrm{p}$ & -
\end{tabular}

Remark : The average number followed by the same letter in row or column shows no significant difference based on DMRT at 5\%; (-) : no significant interaction

Table 11. The effect of lime and gypsum application to the quality of cane juice brix (\%)

\begin{tabular}{|c|c|c|c|c|c|}
\hline \multirow{2}{*}{$\begin{array}{c}\text { Lime } \\
\left(\text { ton } \mathrm{ha}^{-1}\right)\end{array}$} & \multicolumn{4}{|c|}{ Gypsum (ton ha-1) } & \multirow{2}{*}{ Rerata } \\
\hline & 0 & 0.25 & 0.5 & 1 & \\
\hline 0 & 20.93 & 21.61 & 21.21 & 21.17 & $21.23 \mathrm{a}$ \\
\hline 1 & 21.25 & 21.13 & 21.20 & 21.32 & $21.23 \mathrm{a}$ \\
\hline 2 & 21.17 & 21.69 & 20.68 & 20.96 & $21.13 \mathrm{a}$ \\
\hline 3 & 21.01 & 20.64 & 20.67 & 20.68 & $20.75 \mathrm{a}$ \\
\hline Rerata & $21.09 \mathrm{p}$ & $21.27 \mathrm{p}$ & $20.94 p$ & $21.03 \mathrm{p}$ & - \\
\hline
\end{tabular}

minerals. $\mathrm{Cu}$ is taken in the form of $\mathrm{Cu}_{2}{ }^{+}$ion. Copper has an important function in the regulation of plant enzyme systems and in the formation of chlorophyll. Along with zinc, both nutrients are necessary for alkaline and organic soil. The analysis of variance showed that application of lime and gypsum did not give any significantdifferent of copper solubility in thesoil, either at $0-20 \mathrm{~cm}$ or $20-40 \mathrm{~cm}$ depth (Table 7 and 8 ).

The sources of $\mathrm{Zn}$ in the soil are the same as $\mathrm{Cu}$, which are primarily derived from secondary minerals. Zinc also has the same function as copper, which functions in the regulation of plant enzyme systems and in the formation of chlorophyll. Together with copper, these two nutrients are indispensable to alkaline and organic soil. Similar to $\mathrm{Cu}$ element, the result of the $\mathrm{Zn}$ elemental analysis showed that the interaction between lime and gypsum was not significantly different in both soil layers. The application of lime or gypsum also showed no significant effect on changes in $\mathrm{Zn}$ content in the soil (Table 9 and 10).

Brix is a dissolved dry solid in solution ( $\mathrm{g}$ per $100 \mathrm{~g}$ solution) calculated as sucrose. Based on the analysis of quality of cane juice brix did not show significant interaction between lime and gypsum. Similarly, lime or gypsum factors also did not show any significant effect. The treatment resulted in the highest nirabrix in lime treatment 2 ton $\mathrm{ha}^{-1}$ with gypsum 0.25 ton ha $^{-1}$, which was about $21.69 \%$ (Table 11).

Meanwhile, based on the correlation analysis of quality of cane juice brix, there was a positive correlation on $\mathrm{Cu}$. In $\mathrm{Cu}$ element, the correlation to the quality of cane juice can be seen in the layer 0-20 and 20$40 \mathrm{~cm}$ depth (Figures 1 and 2). $\mathrm{Cu}$ element was known to involve in enzyme reaction in plants, including ascorbic acid oxidase, phenolase, and is needed in the early stages of plant development.

\section{Disscusions}

Soil $\mathrm{pH}$ normally required by plants is the $\mathrm{pH}$ which corresponds to the anatomical and physiological of the plant itself. Therefore, modification of soil $\mathrm{pH}$ is necessary in order to meet the plant's needs. This is due to soil $\mathrm{pH}$ determines the availability of nutrients needed by plants. Soil $\mathrm{pH}$ in layer $0-20 \mathrm{~cm}$ depth ranging from 5.77-6.17 which ismoderately acidic and in 20-40 cm depth ranging from 5.11-5.94 which is in acidic-moderately acidic. Analysis of variance on Table 2 and 3 indicated that there are no significant influence of the application of lime and gypsum on soil $\mathrm{pH}$. The initial $\mathrm{pH} \mathrm{H}_{2} \mathrm{O}$ of the soil at 5.0 is already considered relatively acceptable for plant. Therefore, the application of lime and gypsum to increase $\mathrm{pH}$ 


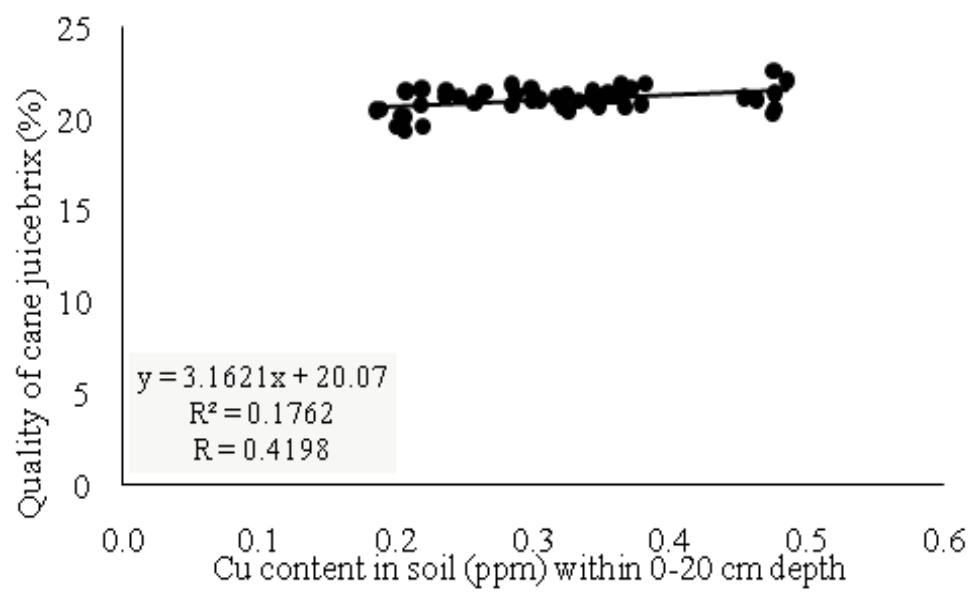

Figure 1. The correlation between $\mathrm{Cu}$ and cane juice quality within $0-20 \mathrm{~cm}$ depth

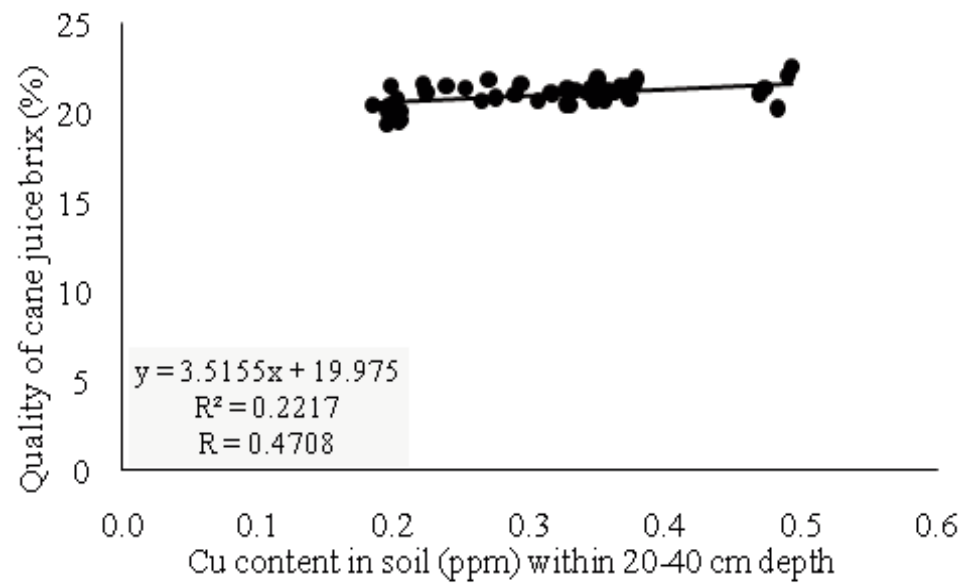

Figure 2. The correlation between $\mathrm{Cu}$ and cane juice quality within $20-40 \mathrm{~cm}$ depth

value is relatively ineffective. In addition, the existence of buffering capacity which is the soil ability to retain $\mathrm{pH}$ changes may be the cause of no significant effects of applied treatments. Based on Fe analysis within $0-20 \mathrm{~cm}$ depth, the application of lime around 2 or 3 ton $\mathrm{ha}^{-1}$ gives the lower result. The more lime applied tends to decrease $\mathrm{Fe}$ availability. Its availability decreases when $\mathrm{pH}$ increases, even though soil $\mathrm{pH}$ has not shown significant differences.Similarly, by adding the dosage of gypsum causes the decrease of Fe solubility. However, the effect of lime and gypsum addition to Fe availability only existsin $0-20 \mathrm{~cm}$ depth, while in $20-40 \mathrm{~cm}$ depth shows no significant difference. This is due to the mixing of lime and gypsum only on topsoil $(0-20 \mathrm{~cm})$ so that the change of $\mathrm{Fe}$ availability has not been seen in thelower layer.

Manganese (Mn) solubility shows no significant difference in lime and gypsum application at 0-20 $\mathrm{cm}$ depth. The only significant difference is in the application of lime for soil analysis of 20-40 cm depth. In general, Mn availability decreases due to the effect of lime application. It is due to the availability of $\mathrm{Mn}$ is greatly influenced by $\mathrm{pH}$, the lower soil $\mathrm{pH}$ the more $\mathrm{Mn}$ is available. The Mn element at low $\mathrm{pH}$ will be dissolved as $\mathrm{Mn}_{2}{ }^{+}$, while at high $\mathrm{pH}$ it will be shown in the form of $\mathrm{MnO}_{2}, \mathrm{Mn}_{3} \mathrm{O}_{4}$, or $\mathrm{MnCO}_{3}$. Compared to the initial soil conditions, it showed an increase in manganese, in top layer from $3.20 \mathrm{ppm}$ at about 5.14-8,87 ppm, while in the lower layers at $1.97 \mathrm{ppm}$ increased to 3.85-6.70 ppm. Mn level on the initial soil is in the low-to-moderate, while the final soil shows at a moderate level.

The analysis of $\mathrm{Cu}$ shows no significant difference either at 0-20 $\mathrm{cm}$ depth or at 20-40 $\mathrm{cm}$ depth. Similar to $\mathrm{Fe}$ and $\mathrm{Mn}, \mathrm{Cu}$ availability is also strongly influenced by soil $\mathrm{pH}$. In an initial soil analysis of copper deficiency, in the final soil analysis, thecopper content of $\mathrm{Cu}$ is sufficiently available. Initial soil analysis showed that at $0-20$ and $20-40 \mathrm{~cm}$ depth $\mathrm{Cu}$ content is 0.14 and $0.11 \mathrm{ppm}$, respectively. However, after the observation, in the final observation, there were an increase in the depth of $0-20$ and $20-40 \mathrm{~cm}$ at about $0.30-0.34 \mathrm{ppm}$ and $0.31-0.33 \mathrm{ppm}$ respectively or recorded an increase of 2.14 and 2,82 times compared to initial observation.

Based on the initial soil analysis, Zn content is in adequate for plants, so the availability of $\mathrm{Zn}$ elements 
for the plant needs to be maintained. After the application, both soil layers showed an increase of $\mathrm{Zn}$ element, such as at the top layer from $0.19 \mathrm{ppm}$ to $0.27-0.42$ ppm. While in $20-40 \mathrm{~cm}$ depth there is an increase of $\mathrm{Zn}$ from $0.10 \mathrm{ppm}$ increased 2-3 times to 0.21 $0.30 \mathrm{ppm}$.

The quality analysis of cane juice brix shows that it is not significantly affected by the application of lime and gypsum which can be said that many factors influenced the quality of cane juice brix. Since another growth parameters show no significant different, the brix quality also shows no difference. The quality of cane juice brix is the calculation of sucrose content that may be more related to nitrogen as anutrient (Franco et al., 2011; Wood et al., 1996) than micronutrients content. This is concluded as the Nitrogen element is more related to photosynthesis process, enzymatic reactions, and sugar formation. Even though $\mathrm{N}$ content is relatively low in plants, it has important roles such as carbon, hydrogen, and oxygen which together forming more than $90 \%$ of plant materials (Dillewijn, 1952).

\section{CONCLUSION}

Soil fertility is dominantly determined by the presence of nutrients, macronutrients, secondary nutrients, and micronutrients. It is commonly found in Ultisols with low acidity that the availability of micronutrient becomes toxic for plants. The applications of lime and gypsum show no significant effect on the micronutrient availability $(\mathrm{Cu}, \mathrm{Zn}$, and $\mathrm{Mn})$ in Ultisols in various depth. The application of lime and gypsum only shows asignificant difference on the application of lime at 3 ton ha ${ }^{-1}$ within $20-40 \mathrm{~cm}$ depth that shows the decrease of Mn content. Meanwhile, the decrease of Fe content takes place by applying lime to thesoil at 2 and 3 ton ha ${ }^{-1}$ within $0-20 \mathrm{~cm}$ depth. It can be concluded that the application of lime about 2 ton hadecreases Fe content in thesoil. Similarly, the application of gypsum at 0.25 ton ha-1 ${ }^{-1}$ hows the decrease of $\mathrm{Fe}$ content at 355.42 ppmcompare to no-gypsum treatment which shows Fe content at $410.34 \mathrm{ppm}$.

\section{REFERENCES}

Alloway, B. J. 1997. Heavy Metals in Soils. 2nd Ed. London: Blackie Academic and Professional - Chapman and Hall.

Augstburger, F., U. Eisenlohr, E. Rüegg, B. Wilhelm. 2002. Manual de Garantía de Calidad Guía para Sistemas De Control Interno (SCI) en organizaciones de pequeños agricultores. Gräfelfing: Naturland.
Basanta, M. V., D. Dourado-Neto, K. Reichart, O. O. S. Bacchi, J. C. M. Oliveira, P. C. O. Trivelin, L. C. Timm, T. T. Tominaga, V. Correchel, F. A. M. Cassaro, L. F. Pires, and J. R. Macedo. 2003. Management Effects of Nitrogen Recovery in A Sugarcane Crop Grown in Brazil. Geoderma, 116: 235-248.

Chorom, M., M. Baghernejad and S. Jafari. 2009. Influence of Rotation Cropping and Sugarcane Production on The Clay Mineral Assemblage. Applied Clay Science, 46. 385-395.

Dariah, A., S. Sutono, N. L. Nurida, W. Hartatik and E. Pratiwi. 2015. Pembenah Tanah untuk Meningkatkan Produktivitas Lahan Pertanian. Jurnal Sumberdaya Lahan, 9(2): 67-84.

Dillewijn, C. V. 1952. Botany of Sugarcane. Waltham: Chronica Botanica.

Franco, H. C. J., R. Otto, C. E. Faroni, A. C. Vitti, E. C. A. Oliveira and P. C. O. Trivelin. 2011. Nitrogen in Sugarcane Derived from Fertilizer Under Brazilian Field Conditions. Field Crops Research, 121: 29-41.

Hardjowigeno. S. 1987. Ilmu Tanah. Jakarta: Mediatama Sarana Perkasa.

Hardjoloekito, A. J. H. S. 2009. Pengaruh Pengapuran dan Pemupukan P Terhadap Pertumbuhan dan Hasil Tanaman Kedelai (Glycine max. L.) pada Tanah Latosol. Media Soerjo, 5(2): 119.

Indrawanto, C., Purwono, Siswanto, M. Syakir and R. Widi. 2010. Budidaya dan Pascapanen Tebu. Jakarta: Eska Media.

Loganandhan, N., B. Gujja, V. V. Goud and U. S. Natarajan. 2013. Sustainable Sugarcane Initative (SSI): A Methodology of 'More With Less'. Sugar Tech, 15(1): 98-102.

Malavolta, E. 1994. Fertilizing for High Yield Sugarcane. International Potash Institute Bulletin, 14: 1-102.

Prasetyo, B. H. and D. A. Suriadikarta. 2006. Karakteristik Potensi dan Teknologi Pengelolaan Tanah Ultisol untuk Pengembangan Pertanian Lahan Kering di Indonesia. Jurnal Litbang Pertanian, 25(2): 39-46.

Rusyanto, A., S. N. H. Utami, and B. H. Purwanto. The Leaching of $\mathrm{Ca}$ and $\mathrm{Mg}$ Cations on The Application of Calcite and Gypsum for Sugarcane Cultivation in Central Lampung Ultisols. International Journal of Agriculture and Environmental Research, 3(3): 3142-3154.

Swift, M. J. and P. Woomer. 1993. Organic Matter and The Sustainability of Agricultural Systems: Definition and Measurement. In: K. Mulongoy and Merckx. R. (Eds.), Soil Organic Matter Dynamics and Sustainability of Tropical Agriculture. 
UK: John Wiley and Sons.

Wijayanti, W. A. 2008. Pengelolaan Tanaman Tebu

(Saccharum officinarum L.) di Pabrik Gula Tjoekir PTPN X, Jombang, Jawa Timur: Studi Kasus Pengaruh Bongkar Ratoon terhadap Peningkatan Produktivitas Tebu. Skripsi. Institut Pertanian Bogor.

Wood, A. W., R. C. Muchow and M. J. Robertson. 1996. Growth of Sugarcane Under High Input Conditions in Tropical Australia, III, Accumulation, Partitioning and Use of Nitrogen. Field Crops Research, 48: 223-233. 